\title{
ОСОБЛИВОСТІ СЕМАНТИЧНОГО Й ПРАГМАТИЧНОГО АСПЕКТІВ ЗООМОРФНИХ ФРАЗЕОЛОГІЗМІВ В АНГЛІЙСЬКІЙ TA УКРАÏНСЬКІЙ МОВАХ
}

Салата I. А. Особливості семантичного й прагматичного аспектів зооморфних фразеологізмів в англійській та українській мовах.

Статтю присвячено зіставному аналізові зооморфних фразем, які виражають моральні якості людини в англійській та українській мовах. Особлива увага звертається на оцінний компонент, тобто схвальну чи несхвальну оцінку, який $є$ основою в конотативному статусі фразеологічної одиниці.

Ключові слова: семантичне значення, прагматичне значення, зооніми, оцінність.

Салата И. А. Особенности семантического и прагматического аспектов зооморфных фразеологизмов в английском и украинском языках.

Статья посвящена сопоставительному анализу зооморфных фразем, которые выражают моральные качества человека в английском и украинском языках. Особое внимание уделяется оценочному компоненту, то есть одобрительной или неодобрительной оценке, который является основой коннотативного статуса фразеологической единицы.

Ключевые слова: семантическое значение, прагматическое значение, зоонимы,оценочность.

Salata I. A. The peculiarities of semantic and pragmatic aspects of phraseological units with zoo component in the English and Ukrainian languages.

The article is devoted to the comparative analysis of phraseological units with zoo component which express moral qualities of people in the English and Ukrainian languages. Special attention is paid to the negative or positive estimation, which is the basis of the connotation of the phraseological unit.

Key words: semantic meaning, pragmatic meaning, zoo component, estimation.

Вивчення фразеології через узаємозв'язок її семантики та прагматики дає змогу здійснювати комплексний підхід до аналізованої царини мовної діяльності.

На думку О. Ф. Арсентьєвої, у різних цивілізаціях та в різні епохи поняття добра і зла, негативного й позитивного осмислюються неоднаково. Представники одного суспільства розцінюють одне й те ж явище індивідуально, хоч існує загальноприйнята точка зору, згідно з якою позитивна чи негативна оцінка входить у структуру значення фразеологічної одиниці $[1$, с. 23].

Зооморфні фразеологізми мають комплексну семантику, у яку інтегрується й прагматичний аспект - оцінка ситуації (особи, предмета) мовцем, інформація про його емоційне ставлення до ситуації, стилістична значущість. Комплексність семантики фразеологізму полягає в тому, що вона містить у собі як предметно-логічні, так і конотативні компоненти. Найважливіші з них такі: 1) переносний чи образний компонент значення 
фразеологізму; 2) прямий чи предметний компонент значення фразеологізму, який складає основу образу та образний стрижень; 3) емоційний компонент; 4) стилістичний компонент; 5) національноетнічний компонент [2, с. 171-172].

На сучасному етапі розвитку лінгвістики під час опису зооморфних фразеологізмів необхідно відзначити важливість ознак, які формують носії мови - емотивність, образність, оцінність. Прагматика - це, як відомо, семантика мови в дії, яка покликана вивчати поведінку знаків у реальних процесах комунікації. Будь-які семантико-прагматичні дослідження спростовують думку про постійне та незмінне значення знака. Значення $є$ процесом, який має свою динаміку. Семантику знака можна уявити як сукупність предметно-логічного, прагматичного та внутрішньолінгвістичного аспектів значення.

Основне знакове призначення фразеологізму - виражати емотивнооцінне відношення до дійсності. «Вершинною» функцією фразеологізму $є$ експресивність. Засобом для іiі створення слугує конотація. У конотацію закладені елементи семантичної динаміки, що можуть здійснювати емоційний уплив на реципієнта, пробуджувати в нього те чи те ставлення до об'єкта референції.

Прагматичне значення, а також комунікативний ефект, який знак створює в умовах певного мовленнєвого акту, зумовлені: 1) оцінністю, яка виникла на основі денотата; 2) емотивністю; 3) безпосереднім образом мотивованої внутрішньої форми та стилістикою [9, с. 3].

Коли учасники комунікативного акту, перебуваючи у стані емоційної напруги, зацікавлені в тому, щоб уплинути на поведінку співбесідника, вони надають власному мовленню афективного забарвлення. Наше зацікавлення викликають емоційно забарвлені слова-характеристики, оцінні одиниці, які функціонують як компоненти зооморфних фразеологізмів. Для правильного використання цих зооморфізмів необхідно відзначити, що в певній ситуації вони мають позитивне чи негативне наповнення i провокують відповідну реакцію партнера. Зооморфізми несуть певну експресію, відображають певну яскраво виражену оцінність. За умов транспозиції вони набувають конотативного значення.

В. Н. Комісаров зазначає, що переносне значення фразеологізму основне, воно обов'язково має відтворюватися під час перекладу. Пряме значення фразеологізму є основою для створення образу, співставляє цей образ із будь-якою сферою життя людини [2, с. 171-172].

Як стверджує I. В. Корунець, «фразеологічне значення - це інваріант інформації, яка виражається семантично ускладненими, окремо оформленими одиницями мови, що не утворюються за структурносемантичними моделями словосполучень» [4, с. 140].

Із зооморфізмами в різних народів пов'язані стійкі асоціації, які проектуються на людину. Вибір уподібнення людини до тварини 
здійснюється задля визначення позитивного чи негативного емотивного ефекту. Образ, створений зооморфізмом, упливаючи на асоціативне мислення людини, стимулює відповідну реакцію.

У статті ми розглянемо фразеологізми, до складу яких входять зооніми, оскільки зооморфні фразеологізми найбільш змістовно виражають емоційно-оцінне ставлення народу як творця цього фразеологізму та користувача, що реагує на якусь ситуацію. Особливу увагу звернемо на оцінний компонент, тобто схвальну чи несхвальну оцінку, яка зафіксована в значенні фразеологізму та $\epsilon$ основою в конотативному статусі ФО у зв'язку з його соціолінгвістичною природою.

У фразеологічній системі англійської та української мов визначаються та діють елементи, загальні для цих мов з одного боку, й національносамобутні, специфічні для кожної мови 3 іншого. Тотожність багатьох зооморфних фразеологізмів у зіставлених мовах пояснюється існуванням спільного фразеологічного фонду для цих мов, унаслідок чого більша частина ФО співпадає не тільки за значенням, але й за структурою, хоч ці мови належать до різних груп.

Серед усіх зоонімів англійської мови у фразеологічних одиницях присутні біля 30 назв тварин. Серед них найчастіше зустрічаються: аре (мавпа), ass (віслюк), bear (ведмідь), beaver (бобер), bull (бик), camel (верблюд), cat (кішка), calf (теля), cow (корова), dog (собака), donkey (віслюк), fox (лисиця), goat (козел), hare (заєць), hog (кабан), horse (кінь), lamb (ягня), leopard (леопард), lion (лев), monkey (мавпа), mule (мул), ox (віл), pig, swine (свиня), rabbit (кріль), rat (пацюк), sheep (вівця), skunk (скунс), squirrel (білка), tiger (тигр), wolf (вовк) та більш ніж 20 назв птахів: chicken (курча), cock (півень), coot (лисуха), crow (ворона), dotterel (сивка), dove (голуб), duck (качка), eagle (орел), goose (гусак), hawk (яструб), hen (курка), јау (сойка, деряба), lark (жайворонок), magpie (сорока), nightingale (соловейко), parrot (горобець), peacock (павич), pigeon (голуб), swan (лебідь), rook (грак), vulture (гриф) та деякі інші. Також зустрічаються зооніми на зразок: bee (бджола), bird (птах), eel (вугор), fish (риба), fly (муха), hound (гончий собака), mouse (миша), snake (гадюка) та ін.

Відповідно в українській мові присутні більше 25 найменувань тварин, серед яких найчастіше уживаються: білка, бик, баран, вовк, ведмідь, вівияя, віл, заєиь, їжак, кінь, кіт, кішка, кобила, коза, козел, корова, кріт, осел, порося, свиня, собака, теля, а також приблизно 15 назв птахів: ворон, ворона, горобець, гуска, індик, кулик, курка, курча, ластівка, лебідь, пава, півень, сич, сорока й інші зооніми: вуж, гадюка, гедзь, джміль, звір, жаба, комар, лин, миша, муха, птах, рак, риба, черв'ячок. 3 погляду на кількісний склад назв тварин у ФО обох мов значної різниці не спостерігаємо.

Серед зоонімів, що характеризують певні якості людини, деякі наділяються лише позитивними чи негативними властивостями. В англійській мові squirrel, lamb, dove, eagle, lark, nightingale асоціюються 
тільки з позитивними рисами. В українській мові практично неможливо виокремити зооніми, які б описували тільки позитивні властивості характеру людини.

Незважаючи на те, що більша частина назв тварин і птахів відображає як позитивні, так і негативні риси людини, можна окреслити групу 3 назвами тварин, які маркують тільки негативні якості. В англійській мові це назви диких тварин: ape, bear, beaver, fox, monkey, rat, skunk, wolf; назви домашніх тварин: ass, donkey, goat, hog, mule, pig; назви диких птахів: coot, doterrel, jay, peacock, pigeon, rook, vulture; назви свійської птиці: duck, goose, hen.

В українській мові це відповідно такі назви диких тварин: ведмідь, вовк, заєцьь, їжак, кріт; назви домашніх тварин: баран, вівця, кіт, кішка, корова, коза, кобила, козел, віслюк, порося, свиня; назви диких птахів: ворон, ворона, пава, сич, сорока; назви свійської птиці: гуска, індик, курка, півень.

Як свідчить проаналізований матеріал (близько 600 зооморфізмів з Англоросійського словника фразеологізмів А. В. Куніна та більше 250 зоофразем iз Фразеологічного словника української мови Г. М. Удовиченка), зооморфні фразеологізми, які метафорично асоціюються 3 людиною, здебільшого виражають негативні значення. Тому кількість зоонімів, що наділяють людину несхвальними якостями, набагато більша, ніж тих, що вказують на позитивні. Це пояснюється сильнішою емоційною реакцією особистості на негативні явища.

Характерною рисою зооморфної фразеології постає наявність в обох мовах численних аналогій, близьких між собою за спільною спрямованістю словосполучень. Збіг образності зооморфних фразеологізмів у різних мовах пояснюється не тільки запозиченнями, але й загальними закономірностями, що спричиняють виникнення близьких фразеологічних одиниць, які демонструють універсальний характер зоонімів у їх здатності та призначенні використовуватися в ролі зоометафор.

Продуктивне використання зооморфізмів постає наслідком того, що людина 3 появою нового об'єкта асоціює його 3 навколишнім світом, із тим, що їй вже знайоме. Під час створення метафор назви тварин мають різний ступінь продуктивності: одні використовуються досить рідко, наприклад, в англійській мові це - camel, coot, dotterel, jay, leopard, peacock; в українській мові відповідно - білка, кулик, ластівка, пава, кріт; інші дуже часто: в англійській мові - ass, dog, fox, horse, lion, rat, sheep; в українській мові - бик, кінь, кіт, коза, кішка, муха, свиня, собака.

Особливість зіставного аналізу ФО полягає в необхідності врахувати первинні системи (лексичну та граматичну), а також специфіку їхніх виявів у фразеології. Основоположним у порівняльному аналізі різних мов $\epsilon$ не ототожнення певних одиниць, а визначення схожості та відмінності зіставлюваних одиниць. Тоді мова йтиме про відносну тотожність. 
Установлення міжмовних фразеологічних еквівалентів різних типів задовольняє потреби перекладу та навчання іноземних мов.

За ступенем функціонально-смислового співвіднесення англійських та українських зооморфних фразеологізмів можна визначити три типи співвідношення зооморфних фразем - еквівалентів у зіставлених мовах: 1) повна семантична відповідність - повні еквіваленти; 2) неповна відповідність - часткові еквіваленти; 3) відсутність відповідних ФО безеквівалентні ФО. Це питання досить детально розглянула у своїй статті «Особливості міжмовних еквівалентів англійських зоофразеологізмів в аспекті перекладу» Л. О. Ярова [8].

Ми ж приділимо увагу зіставному аналізові зооморфних фразем, які виражають моральні якості людини в англійській та українській мовах, оскільки сучасна лінгвістика при зіставному аналізі основним напрямком вивчення зооморфних ФО висуває універсальні, міжмовні відношення на основі культурологічно релевантних ознак.

У складі ФО визначаються, як правило, негативний, позитивний та нейтральний компонент фразеологічного значення, в основу якого покладено засудження, схвалення або відсутність чітко виражених характеристик як конотація соціально закоріненої оцінки будь-якого явища. «Асоціативно-образний зв'язок, що лежить в основі непрямої фразеологічної номінації, не тільки сприяє адекватному декоруванню змісту висловлювання, але й виступає стимулом для появи в адресата оцінної та емоційної реакції» [2, с. 38]. Умовно розподілимо ці мовні одиниці на кілька груп, об'єднаних тою чи тою семантичною особливістю: 1) зооморфні фразеологізми, які називають позитивні риси людини; 2) зооморфні фразеологізми на позначення негативних рис; 3) зооморфні фразеологізми, що ілюструють нейтральне сприйняття певної події.

У межах статті немає змоги подати більш розлогу класифікацію зооморфних фразеологічних одиниць, тому обмежимося кількома прикладами. Серед стійких виразів, що називають позитивні якості людини, виокремлено такі:

- працьовитість: в англійській мові. A busy bee has no time to sorrow працьовита бджола не має часу сумувати: He who would catch fish must not mind getting wet - без труда нема плода; The dog that trots about finds a bone - собака, який бігає, знайде кістку; All lay loads on a willing horse - хто везе, того ще й підганяють; Work like a horse - працювати, як кінь; Busy as a bee - працьовитий, як бджола; Like a squirrel in a cage - як білка у клітці; в українській мові. Бджола мала, а ц̌ та праиює; Праџьовитий, як бджола; Хто чого шукає, той знайде; Праџює, як віл; Праџює, як чорний віл; Крутиться, як муха в окропі; Вертиться, наче в'юн в ополониі; Крутиться, наче в'юн на сковорідиі; Крутиться, як посолений в'юн; Крутиться, як дзита; Крутиться як муха в окропі; Щоб рибу їсти, треба в воду лізти; 
- сміливість, рішучість: в англійській мові: The bull must be taken by the horns - взяти вола за роги; To beard the lion in his den - напасти на лева у його логові; Don't make yourself a mouse, or the cat will eat you - не будь вівцею, то і вовк не з'ість; Fight like a lion - битися, як лев; Show the bullhorn - показувати зуби, чинити опір; Bold like a lion - сміливий, як лев; в українській мові: Брати бика за роги; Ловити (піймати) вовка за вухо; Взяти вола за роги; Не будь бараном, то й вовк не з йсть; Назад тільки раки лазять;

- обачність, обережність: в англійській мові: The mouse that has but one hole is quickly taken - мишу, яка має тільки одну нору, легко піймати; Catch the bear before you sell his skin - впіймай ведмедя перш, ніж продавати його шкуру; It is ill to waken sleeping dogs. Let sleeping dogs lie не буди собак, які сплять; When the fox preaches, take care of your geese коли лисиця молиться, бережи своїх гусей; The scaled dog (cat) fears cold water - хто обпікся на окропі, той і на холодну воду дмухає; Don't put cart before the horse - не ставте віз перед конем; в українській мові: I вовки ситі, і вівці изілі; Хто обпікся на молоцуі, той на воду дмухає; Не буди лихо, поки воно спить.

Як вже було зазначено, кількість зооморфних ФО 3 негативною ознакою набагато більша, особливо це властиво українській мові. Наведемо кілька прикладів:

- дурість: в англійській мові: Every ass likes to hear himself bray кожен осел любить своє ревіння слухати; The cow knows not what her tail is worth until she has lost it - корова не цінує хвоста, поки його не втратить; It's a silly fish that is caught twice with the same bait - дурна та риба, яка двічі попадає на одну приманку; в українській мові: Кожна лисиия свій хвостик хвалить, а чужий ганить; 3 живого ведмедя икуру ділити (пропивати); Вовк ще в лісі, а вони вже икуру ділять;

- боягузтво: в англійській мові: Hares may pull dead lions by the beardмертвого лева і зайці за бороду смикати можуть; Rats desert a sinking ship як щури $з$ корабля; As brave as a lion with a lamb - хоробрий, як лев 3 ягням; в українській мові: Заяча душа; Мертвий пес не вкусить;

- хитрість, лицемірство: в англійській мові: $A$ wolf in a sheep's clothing - вовк в овечій шкурі; A cat has nine lives - кішка має дев'ять життів; Sly $d o g$ - хитрий лис; As slippery as an eel - слизький, як вугор; As cunning as a fox - хитрий, як лис; One cannot run with the hare and hunt with the houndsслужити і вашим, і нашим; Play the fox - хитрувати; в українській мові: Погляд лисячий та вовча думка; Вигріти гадюку в пазусі; Говорить як лисиця, а за пазухою камінь держить; Коти приховують свої кігті;

- бундючність, гордість: в англійській мові: An ass in a lion's skin віслюк в лев'ячій шкірі; Every dog is a lion at home - кожний собака вдома лев. Pigs in clover - гордовитий; в українській мові: Як пава; Яке цабе; Як порося на орчику (величатися); Мов куций бик у череді; Коли б свині роги; 
- хвастливість: в англійській мові: Each bird loves to hear himself sing кожна пташка свою пісню співає; A beggar on the horseback - ворона в павичевому пір'ї; Every bird likes his own nest - усякий кулик до свого болота звик; в українській мові: Кожна жаба своє болото хвалить;

- жадібність: в англійській мові: Dogs that put up many hares kill nothing - за все братись, нічого не зробити; A dog in the manger - собака на сіні; в українській мові: За двома зайчями побігти -жодного не спіймати.

Приклади зооморфних фразеологізмів, що ілюструють нейтральне сприйняття певної події: To live cat-and-dog life - жити як кішка з собакою. The great fish eat the small - велика риба з'їдає маленьку; A bird may be known by its flight - видно птаха по польоту; It is a good horse that never stumbles - кінь на чотирьох ногах та спотикається. One must howl with the wolves - з вовками жити, по-вовчому вити.

Фразеологізми, до складу яких входить зоонімічна лексика, $\epsilon$ найчисленнішою групою для обох мов; вони можуть вивчатися як унікальний матеріал для визначення когнітивних, семантичних та прагматичних аспектів мовлення представників будь-якого етносу.

Зооморфні фразеологізми заслуговують більш детального дослідження, адже, вони утворюють певну підсистему зі своїми закономірностями, які, незважаючи на універсальність зоонімічної лексики, вимагають додаткового лінгвістичного аналізу. Зоонімічна лексика, що входить до складу зооморфного фразеологізму, характеризується національнокультурною специфікою відображення картини світу в мові і в той же час фіксує певні моменти загальної культури.

\section{Література}

1. Арсентьева Е. Ф. Сопоставительный анализ фразеологических единиц : на материале фразеологических единиц, семантически ориентированных на человека в английском и русском языках / Елена Федоровна Арсеньева. Казань : Изд-во Казан. ун-та, 1989. - 124 с.

2. Карташкова Ф. И. Номинативный аспект фразеологических имен Ф. И. Карташкова // Теория языка и речи : история и современность. Иваново, 1999. - С. 31-39.

3. Комиссаров В. Н. Современное переводоведение / Вилен Наумович Комиссаров. - М. : ЭТС, 2001. - 424 c.

4. Корунець I. В. Теорія і практика перекладу (аспектний переклад) : [підручник]. - Вінниця : Нова книга, 2001. -448 с.

5. Кунин А. В. Большой англо-русский фразеологический словарь / А. В. Кунин. М. : Высшая школа, 1996. - 942 с.

6. Кунин А. В. Курс фразеологии современного английского языка / А. В. Кунин. М. : Высшая школа, 1996. - 381 с.

7. Удовиченко Г. М. Фразеологічний словник української мови / Г. М. Удовиченко : [у 2 т]. - Київ : Головне видавництво видавничого обєднання «Вища школа», 1984. - T.1- 304 c., T. $2-384$ c.

8. Ярова Л. О. Особливості міжмовних еквівалентів англійських зоофразеологізмів 
в аспекті перекладу // Культура народов Причерноморья. - №5, том № 3, листопад 2003. - Сімферополь, 2003. - С. 150-155.

9. Юрченко Д. В. Структурно-семантические и номинативно-мотивационные свойства зоонимических фразеологизмов немецкого языка : атореф. дис. на соискание науч. степени канд. филол. наук : спец. 10.02.04 «Немецкий язык» / Д. В. Юрченко. - Пятигорск, 2001. - 20 с.

Стаття надійшла до редакиії 26.10.2010 p. 